\title{
脳腫瘍に対する陽子線治療
}

\author{
吉井与志彦·牧豊·成岛 浄 - 高野 晋吾 - 橋川 正典·能勢 忠男

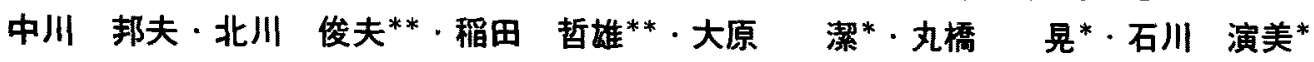 \\ 高倉 公朋 $* * *$. 喜多村孝—****
}

\section{Use of Radiotherapy by High-energy Protons in the Postoperative Treatment of Brain Tumor}

\author{
Yoshihiko YoshiI, Yutaka Maki, Akira Narushima, Shingo TaKano, \\ Masanori Hashikawa, Tadao Nose, Kunio Nakagawa, Toshio KitagaWa**, \\ Tetsuo INADA**, Kiyoshi OOHARA*, Akira MARUHASHI*, Nobuyoshi IshIKaWA*, \\ Kintomo TAKaKURA ${ }^{* * *}$ and Koichi KITAMURA****
}

Departments of Neurological Surgery and ${ }^{*}$ Radiology, Institute of Clinical Medicine, and ${ }^{* *}$ Particle Radiation Medical Science Center, University of Tsukuba, Ibaraki; ${ }^{* * *}$ Department of Neurosurgery, University of Tokyo, Tokyo; ${ }^{* * * *}$ Department of Neurosurgery, Neurological Institute, Tokyo Women's Medical College, Tokyo

\begin{abstract}
Fractionated irradiation using 250 mega electron volt protons alone or in combination with ${ }^{60}$ cobalt $(\mathrm{Co})$ gamma ray was given postoperatively to 8 patients with glioma and 2 patients with meningioma. A single field was used for all patients. The irradiated field varied from 28 to $144 \mathrm{~cm}^{2}$; the irradiated depth was from 6 to $11 \mathrm{~cm}$ and the width of the Bragg peak was from 5 to $10 \mathrm{~cm}$ in the proton radiotherapy. Dose aim was approximately $74.5 \mathrm{Grey}(\mathrm{Gy})$ over 46 days in the proton alone radiotherapy and was approximately $84.8 \mathrm{~Gy}$ over 56 days in the combined therapy with ${ }^{60} \mathrm{Co}$ gamma ray. The dose increment was from 2.5 to $5.0 \mathrm{~Gy}$ per fraction as treatment progressed in the proton radiotherapy. No evident increased intracranial pressure developed. Nine patients were given the planned dose of irradiation. One patient with glioblastoma multiforme deteriorated during the treatment and the planned course was not completed. The patient was reoperated. Another patient with glioblastoma multiforme deteriorated 1 month after planned irradiation of $84.2 \mathrm{~Gy}$ and was diagnosed as having a regrowth of the tumor. Evident and viable tumor cells were observed in the outline of the center of tumor tissue in the irradiated field. Furthermore no evident radiation effect developed in the peritumoral area showing low density on computerized tomography. Exudative dermatitis with much epilation was seen at the proton beam entrance site in all patients with complete radiotherapy. Seizure was also seen in 6 out of 9 patients. Two patients with grade III or II astrocytoma and 2 patients with meningioma were in good health 6 to 9 months after radiotherapy, but the other patients with glioblastoma multiforme died or deteriorated 1 to 5 months after radiotherapy. The issue of proton radiotherapy for brain tumor was discussed. In conclusion, it is necessary to investigate further the optimal dose and dose distribution in the tumor tissue, irradiation technique, and the combined therapy with some drug in the treatment of malignant glioma.
\end{abstract}

Key words: brain neoplasms, proton, radiotherapy, histology

\begin{tabular}{|c|c|}
\hline $\begin{array}{l}\text { 筑波大学臨床医学系脳神経外科 }{ }^{*} \text { 同放射線科 } \\
\text { ****東京女子医科大学脳神経センター脳神経外科 }\end{array}$ & **筑波大学粒子線医科学センター ***東京大学脳神経外科 \\
\hline $\begin{array}{r}\text { Address reprint requests to: Y. Yoshii, M.D., Departmen } \\
1 \text { Amakubo, Sakura-mura, }\end{array}$ & $\begin{array}{l}\text { nt of Neurological Surgery, Institute of Clinical Medicine, University of Tsukuba, 3-1- } \\
\text { Niihari-gun, Ibaraki } 305 .\end{array}$ \\
\hline 受稿 1984年12月24日 受理 1985年9月9日 & \\
\hline
\end{tabular}




\section{Iはじめに}

悪性脳腫瘍に対して手術後, 集学的療法として放射線治 療や化学・免疫療法を用いることは現在ではごく一般的と なっている。術後の放射線治療は1960年代に普及した高工 ネルギーX 線治療法により向上したが，それから20数年 を経た現在，同調期放射線治療法や種々の化学潦法を併用 しても，悪性脳腫瘍に対する高エネルギーX 線治潦法も 限界に達している感がある。一般には放射線量を増せば腫 瘍細胞が死隇することは固型腫演や培養細胞によって確か められている5,14)。しかし， ${ }^{60} \mathrm{Co} \gamma$ 線，LinacX 線などの 従来の放射線治療では正常組織の放射線耐容線量と腫瘍組 織の放射線効果線量との兼社合いで投与しうる治療線量に 限界がある。このことは，治療線量が結果的に抗腫瘍効果 線量として果して妥当か否かという問題を含んでいる。一 方, 強力な傷害修復能力を有する腫瘍細胞や低酸素状態で も生存可能である腫膓細胞に対しては従来の放射線機器単 独治療では無力で，有効な薬剂を併用していかに放射線効 果を増強させるかが模索されている．従来の放射線治療が 持つこれらの線量分布に関する問題と放射線抵抗性に関す る問題を解決寸る可能性のあるのが粒子線治療法である.

粒子線治療法の一つである陽子線治療法は，すでに世界 各国で臨床応用されている。1980年, 筑波大学粒子線医科 学センター(以下粒医セ) に水平陽子線および垂直陽子線照 射装置が設置された。粒医セの陽子線エネルギーは, 他施 設でのエネルギーが 50〜185 MeV と低いのに比べ, 250 $\mathrm{MeV}$ とはるかに高いのが特徴である。このことは, 200 $\mathrm{MeV}$ の陽子線エネルギーが組織内では $25 \mathrm{~cm}$ の深さに Bragg peak(ある一定の深さの飛程近傍で一挙にエネルギ 一を放出する効果) 形成する゙のので, $250 \mathrm{MeV}$ の陽子線 エネルギーはいかなる部位の深部病巣にも Bragg peakを 形成しうることを意味している，我々は本装置を1983年 4 月から臨床応用し，一部に陽子線照射後再手術を行い，組 織学的検索を行う機会を得たので, その治療法の概略, 問 題点について報告する.

\section{III装置および線量分布}

高エネルギー物理研究所のブースターシンクロトロンよ り供給される $500 \mathrm{MeV}$ の陽子線を減速機で $250 \mathrm{MeV}$ のエ ネルギーまで落として使用するが，まず照射野形成のため に，(1)陽子線線束が大きな照射面積でも均等な分布を示す こと，(2)飛程㧍よび Bragg peak 幅を任意に調整できるこ と，(3)線量㧍よびビーム位置，形状のモニターが確実にで きることの 3 点が必要であったり

均等な線量分布を得るためには，厚さ $5 \sim 15 \mathrm{~mm}$ の銅板
と一重リングを用いたリング散乱体方式が用いられた。 そ して，2 種類のコリメーターを用いて不整形照射野を形成 し, 厚さ $3 \mathrm{~cm}$ の真鏯片を各種の形状に組み合せて患者皮 覤面より2〜3cm の距離に置くことによって均等な線量 分布が得られた。ついで至適な飛程を得るために, $5 \mathrm{~mm}$ 厚のアクリル板を重ねることによって病巣最深部よりも深 部の正常組織に照射されないように補正された。単一エネ ルギー陽子線の Bragg peak 幅は数 $\mathrm{mm}$ しかないので, 適 当な幅に拡大するためには所要の厚さと面積から成る䒜状 の陽子線エネルギー吸収体(リッジフィルター)が用いら れ，これに幾種類かの飛程の陽子線を入射させて至適な Bragg peak幅が得られた。このようにして得られた線量 分布の典型例は Fig. 1 のようになる．なお，粒医セの陽 子線はパルスビームであり，その瞬間線量率が高いので, 線量のモニターは有効径約 $20 \mathrm{~cm}$ の平行平板電極型真空 チャンバーを一次散乱体下部扝よびリング下部に設置して 行われた。 また，ビーム形状および位置は最終的には照射 装置においてダイオード检出器自動走查装置(Theradose 社)によって確認された7).

治療計画については稲田ら吾の報告があり，詳細は省く が, CT 画像に基ぶいて(1)組織内不均等密度の補正と(2)病 巣および体表の形状補正を正確に行うことであった。

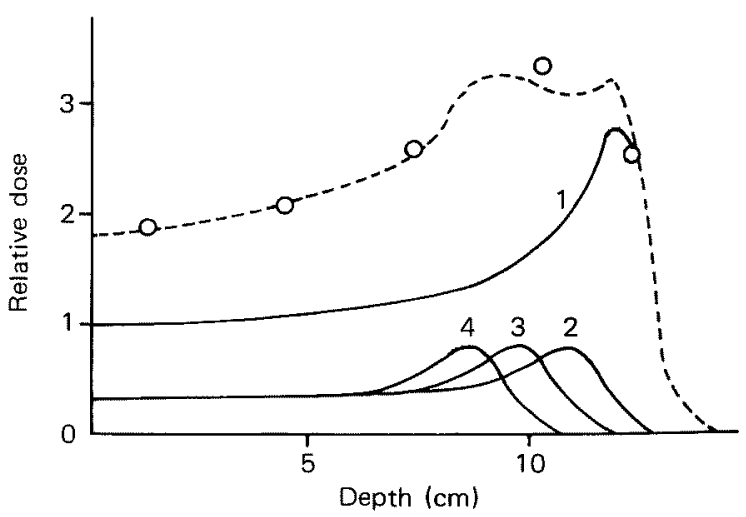

Fig. 1 Modulated depth dose distribution for 250 mega electron volt $(\mathrm{MeV})$ proton. Curve 1 is the depth dose distribution for the primary beam of $250 \mathrm{MeV}$ protons at the Particle Radiation Medical Science Center, which has $1.0 \mathrm{~cm}$ half-width at the Bragg peak. Curves 2 through 4 are the depth dose distributions for the primary beams of lower intensities and shorter ranges. The calculated curve (dotted line), which is the result of summing all of the individual Bragg peaks of the beams of varying ranges, forms a uniform dose at a range of 9 through $12 \mathrm{~cm}$ in this illustration. The calculated curve corresponds to the depth doses (circles) measured by a dosimeter. 
(1)においては, 病巣およびそれに至る各組織を水の層に 換算して必要な線量を求める方法がとられた. これは，お のおのの陽子線の Bragg peak を形成する深さが水中で比 較的容易に測定できるためである. すなわち, 水の相対電 子密度値を 1 として水の CT 值に対する各組織の CT 值か ら各組織の相対電子密度値を求め, これを照射線束上の各 組織のピクセル 1 個 1 個について求め, 各ピクセルの相対 電子密度値を乗じて合計した值がその照射線束上の各組織 を水の層に置換した換算値として求められた. たとえば, ピクセル 1 個が $4 \mathrm{~mm} \times 4 \mathrm{~mm}$ である線束上の病巣が 10 個 のピクセルで占められ, 各ピクセルの相対電子密度值を CT 值から換算した結果， 5 個のピクセルでは扝のおの

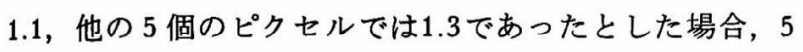
(個) $\times 1.1 \times 4(\mathrm{~mm})=22(\mathrm{~mm}), 5($ 個 $) \times 1.3 \times 4(\mathrm{~mm})=$ $26(\mathrm{~mm}), 22+26=48(\mathrm{~mm})$, すなわち $40 \mathrm{~mm}[10$ (個) $\times 4$ $(\mathrm{mm})$ )の幅の不均等密度から成る組織は $48 \mathrm{~mm}$ の水の層 の厚さ(幅)に換算されることになり, 結局 $48 \mathrm{~mm}$ の水の 層に換算された病巣組織の幅全体に陽子線が照射される線 量が求められる訳である.

(2)においては，照射線束上の最深部の腫瘍および体表形 状を組織等価物質 Mix DP 製のボーラスを使って補正し, 陽子線高線量域がそれより深部に到達しないようにされた (Fig. 2A).すななわち，まず初めに CT 上で陽子線線束上 において脳表から病巣最深部までの深さをピクセル数から 求め, この深さを陽子線が水の層で到達する深さから引い た値をボーラスの厚さとした．たとえば，1 ピクセルが 4 $\mathrm{mm} \times 4 \mathrm{~mm}$ から成り, 照射線束上において脳表から病巣 最深部までピクセル数が30個であったと寸れば30(個) $\times 4$ $(\mathrm{mm})=12(\mathrm{~cm}), 250 \mathrm{MeV}$ の陽子線が水の層では $38 \mathrm{~cm}$ ま で到達するとすれば $38-12=26$, したがって $26 \mathrm{~cm}$ の厚 さのボーラスを線束上の頭皮上に置いておかなければ病巣 最深部を突き抜けてしまうことになる．Fig. 2B は以上の ようにして求められた線量分布の 1 例である.

照射部位の決定に際しては，現時点では CT で腫瘍浸潤 部を正確に診断することは困難であるので，増強部および その周囲低吸収域を含めて照射範囲として CT 画像上に trace し，前述の操作をModulex 計算機(CMS 社, 2110 型)にて処理し，線量分布が算出された(現在ではVAX 11/750計算機に接続したシステムによって自動的に線量計 算を行っている).

\section{III 対象および方法}

対象は神経膠腫 3 例, 多型性神経膠芽腫 5 例, 髄膜腫 2 例(再発悪性㵦膜腫 1 例, 傍鞍部咀膜腫 1 例)の計 10 例で, いずれも術後残存部腫瘍に対して治療が行われた(Table
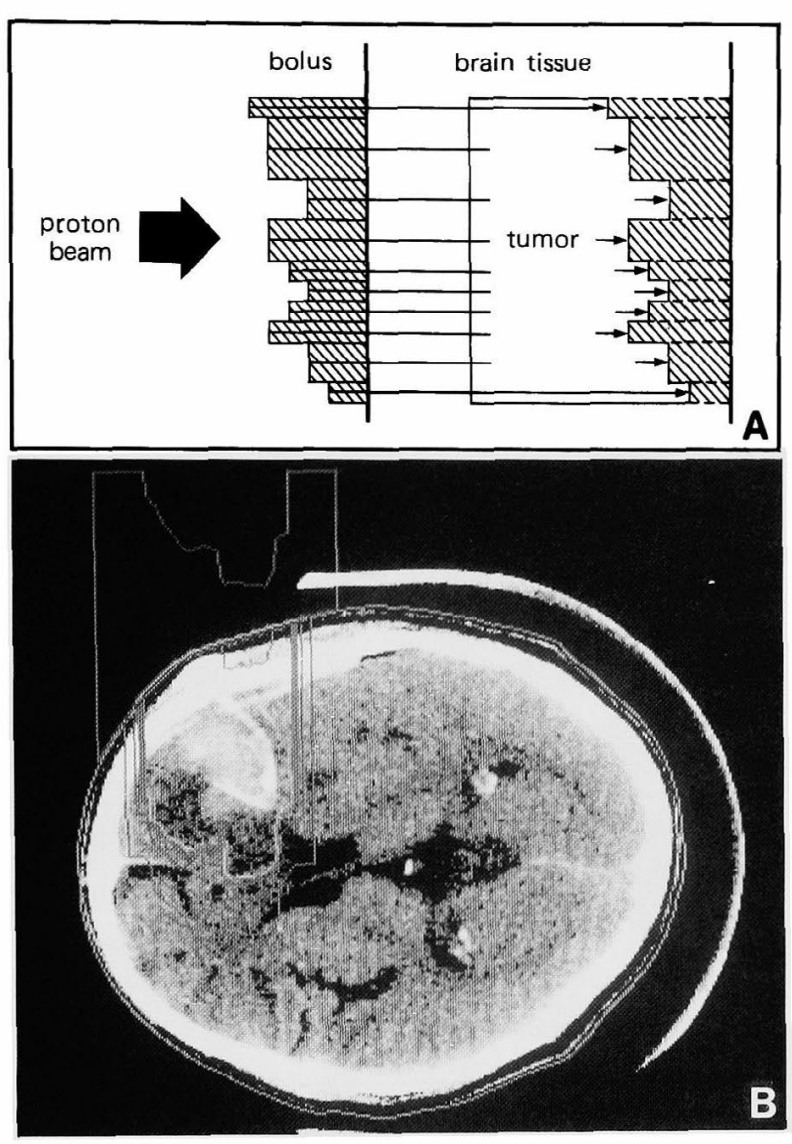

Fig. 2 Diagram showing construction of an adequately compensating bolus. The material of the bolus is equivalent in penetration to tissue. A: The bolus must be designed to adjust the proton beam penetration over the entire field to the desired depth. B: Cross sectional contour of the bolus and outline of the proton field on computerized tomography (CT) designed for the treatment of Case 1.

1). 放射線治療を計画通り終了したのは 9 例で，そのなか で陽子線単独治療は 2 例, ${ }^{60} \mathrm{Co} \gamma$ 線併用治療は 7 例であっ た. 放射線治療中止例は多型性神経膠芽腫の 1 例で, 陽子 線 $31.5 \mathrm{~Gy}$ 照射時点で神経症状の悪化と CT 所見での腫瘍 増強部の増大により再手術を行った症例である. また, 神 経膠腫の 1 例は ${ }^{60} \mathrm{Co} \gamma$ 線 $50.6 \mathrm{~Gy}$, 陽子線 $35 \mathrm{~Gy}$ を照射さ れたが，1 カ月後神経症状の若干の低下のために陽子線 $29 \mathrm{~Gy}$ を追加照射された.

照射は患側一門固定で行われ，9例では側頭方向から， 1 例の傍矢状洞部再発髄膜腫例では半坐位にて頭頂方向か ら照射された．放射線治療を終了した 9 例の陽子線治療条 件は, 照射野面積 $28 \sim 144 \mathrm{~cm}^{2}$, 照射深度 $6 \sim 11 \mathrm{~cm}$, また Bragg peak 幅は 5〜10 cm に拡大されて照射された. 
Table 1 Radiotherapy by high energy protons in the postoperative treatment of brain tumor

\begin{tabular}{|c|c|c|c|c|c|c|c|c|c|c|}
\hline \multirow[b]{2}{*}{$\begin{array}{l}\text { Case } \\
\text { No. }\end{array}$} & \multirow[b]{2}{*}{$\begin{array}{l}\text { Age } \\
(\text { year }) / \\
\text { Sex }\end{array}$} & \multirow[b]{2}{*}{ Diagnosis } & \multicolumn{4}{|c|}{$250 \mathrm{MeV}$ proton $\mathrm{RT}$} & \multicolumn{2}{|c|}{${ }^{60} \mathrm{Co} \mathrm{RT}$} & \multirow{2}{*}{$\begin{array}{l}\text { Interval } \\
\text { between } \\
\text { proton } \mathrm{RT}^{\mathrm{T}} \\
\text { and }{ }^{60} \mathrm{Co} \\
\mathrm{RT} \text { (day) }\end{array}$} & \multirow[b]{2}{*}{ Outcome } \\
\hline & & & $\begin{array}{c}\text { Ir- } \\
\text { radiated } \\
\text { field } \\
(\mathrm{cm})\end{array}$ & $\begin{array}{l}\text { Ir- } \\
\text { radiated } \\
\text { depth } \\
(\mathrm{cm})\end{array}$ & $\begin{array}{l}\text { Width } \\
\text { of } \\
\text { Bragg } \\
\text { peak } \\
(\mathrm{cm})\end{array}$ & $\begin{array}{c}\text { Total dose } \\
(G y) / \\
\text { Treatment } \\
\text { time (day) }\end{array}$ & $\begin{array}{l}\text { Irradiation } \\
\text { method }\end{array}$ & $\begin{array}{c}\text { Total dose } \\
\text { (Gy)/ } \\
\text { Treatment } \\
\text { time (day) }\end{array}$ & & \\
\hline 1 & $52 / \mathrm{M}$ & $\begin{array}{l}\text { astrocytoma } \\
\text { grade II }\end{array}$ & $8 \times 13$ & 11 & 8 & $55.5 / 32$ & $\begin{array}{l}\text { before } \\
\quad \text { proton RT }\end{array}$ & $30.5 / 28$ & 13 & $\begin{array}{l}\text { good, } 9 \text { mo. } \\
\text { after proton RT }\end{array}$ \\
\hline 2 & $70 / \mathrm{M}$ & $\begin{array}{l}\text { glioblastoma } \\
\text { multiforme }\end{array}$ & $8 \times 12$ & 8 & 10 & $43.0 / 18$ & $\begin{array}{l}\text { before } \\
\quad \text { proton } R T\end{array}$ & $40.0 / 44$ & 38 & $\begin{array}{l}\text { death, } 5 \text { mo. } \\
\text { after proton } \mathrm{RT}\end{array}$ \\
\hline 3 & $61 / \mathrm{M}$ & $\begin{array}{l}\text { glioblastoma } \\
\text { multiforme }\end{array}$ & $10 \times 8$ & 10 & 8 & $57.5 / 32$ & $\begin{array}{l}\text { before } \\
\quad \text { proton RT }\end{array}$ & $15.0 / 18$ & 10 & $\begin{array}{l}\text { reoperation, } 3 \text { mo. } \\
\text { after proton } \mathrm{RT}\end{array}$ \\
\hline 4 & $58 / \mathrm{M}$ & $\begin{array}{l}\text { glioblastoma } \\
\text { multiforme }\end{array}$ & $9 \times 10$ & 7 & 8 & $54.0 / 32$ & $\begin{array}{l}\text { before } \\
\quad \text { proton RT }\end{array}$ & $30.2 / 28$ & 6 & $\begin{array}{l}\text { reoperation, } 1 \mathrm{mo} . \\
\text { after proton } \mathrm{RT}\end{array}$ \\
\hline 5 & $59 / \mathrm{M}$ & $\begin{array}{l}\text { glioblastoma } \\
\text { multiforme }\end{array}$ & $10 \times 8$ & 8 & 6 & $76.5 / 45$ & - & - & - & $\begin{array}{l}\text { poor, } 5 \text { mo. } \\
\text { after proton } \mathrm{RT}\end{array}$ \\
\hline $6^{*}$ & $53 / \mathrm{F}$ & $\begin{array}{l}\text { glioblastoma } \\
\text { multiforme }\end{array}$ & $13 \times 9$ & 10 & 8 & $31.5 / 24$ & - & - & - & $\begin{array}{l}\text { reoperation, } 1 \text { mo. } \\
\text { after incomplete } \\
\text { proton RT }\end{array}$ \\
\hline 7 & $37 / M$ & astrocytoma & $7 \times 7$ & 9 & 5 & $47.0 / 18$ & $\begin{array}{l}\text { after } \\
\quad \text { proton RT }\end{array}$ & $24.2 / 21$ & 9 & $\begin{array}{l}\text { poor, } 3 \text { mo. } \\
\text { after }{ }^{60} \mathrm{Co} \mathrm{RT}\end{array}$ \\
\hline \multirow[t]{2}{*}{8} & \multirow[t]{2}{*}{$40 / \mathrm{M}$} & \multirow[t]{2}{*}{$\begin{array}{c}\text { astrocytoma } \\
\text { grade III }\end{array}$} & $12 \times 12$ & 8 & 8 & $35.0 / 19$ & \multirow{2}{*}{$\begin{array}{l}\text { before } \\
\text { proton RT } \\
-\end{array}$} & $50.6 / 42$ & 104 & $\begin{array}{l}\text { poor, } 1 \text { mo. } \\
\text { after proton RT }\end{array}$ \\
\hline & & & $11 \times 14$ & 10 & 10 & $29.0 / 18$ & & - & - & \\
\hline 9 & $46 / \mathrm{F}$ & $\begin{array}{l}\text { recurrent } \\
\text { meningioma }\end{array}$ & $6 \times 14$ & 6 & 6 & $72.5 / 46$ & - & - & - & $\begin{array}{l}\text { good, } 7 \text { mo. } \\
\text { after proton RT }\end{array}$ \\
\hline 10 & $71 / \mathrm{F}$ & meningioma & $4 \times 7$ & 10 & 6 & $64.5 / 24$ & $\begin{array}{l}\text { after } \\
\quad \text { proton } R T\end{array}$ & $17.3 / 15$ & 13 & $\begin{array}{l}\text { good, } 6 \text { mo. } \\
\text { after }{ }^{60} \mathrm{Co} \text { RT }\end{array}$ \\
\hline
\end{tabular}

*Incomplete radiotherapy. $\mathrm{MeV}$ indicates mega electron volt; RT, radiotherapy; Co, cobalt; Gy, Grey; mo., month.

陽子線の生物学的効果( relative radiobiological effectiveness; 以下 RBE)算定は，それがピーク域やプラトー域を 持っていて微妙に異なるが，160〜 $200 \mathrm{MeV}$ の陽子線では

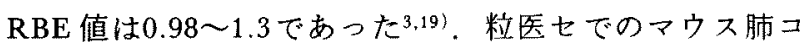
ロニー・アッセイ ${ }^{2)}$ 技よびマウス皮䖉反応の結果も ${ }^{60} \mathrm{Co} \gamma$ 線とほぼ同等であった。したがって，粒医セの $250 \mathrm{MeV}$ の陽子線の RBE 值を 1.0 として臨床応用への線量計算を行 った.

陽子線治療の場合には, machine time の都合で 1 回線 量 2.5 5 Gy, 1 週間 3 5 日の分割で照射された。一方, ${ }^{60} \mathrm{Co} \gamma$ 線治療の場合には 1 回線量 1.8 2 Gy, 1 週間 5 日 の分割で照射された，病巣総線量は，陽子線単独では平均 $74.5 \mathrm{~Gy},{ }^{60} \mathrm{Co} \gamma$ 線との併用では平均 $84.8 \mathrm{~Gy}$ であった。 な お， ${ }^{60} \mathrm{Co} \gamma$ 線との併用は 7 例中 5 例では陽子線治療前に, 2 例で注治療後に行われ， ${ }^{60} \mathrm{Co} \gamma$ 線と陽子線治療との治療 休止期間は最低 6 日から最高104日，平均28日であった。

\section{IV 治 療結 果}

多型性神経膠芽腫 5 例のうち，1 例は陽子線治療中，総 線量 $31.5 \mathrm{~Gy}$ で神経症状増悪し，治療を中止して手術を行
った。 また， 2 例(陽子線と ${ }^{60} \mathrm{Co} \gamma$ 線併用治療で総線量 $72.5 \mathrm{~Gy}$ と $84.2 \mathrm{~Gy}$ ) は放射線治療後 1〜3力月で臨床症状 およびCT 所見から腫瘍再発育と診断され, 再手術が行わ れた。他の 1 例(陽子線之 ${ }^{60} \mathrm{Co} \gamma$ 線併用治療で総線量 83 Gy) は放射線治療後 5 力月で肺炎を合併して死亡した。 残 り1例と神経膠腫の1例(陽子線単独治療で総線量 76.5 Gy ${ }^{60} \mathrm{Co} \gamma$ 線併用治療で総線量 $\left.71.2 \mathrm{~Gy}\right)$ は放射線治療後 3〜5 力月で腫湯再発育と診断されているが， inoperableの 状態にある。 以上のように，5例の多型性神経膠芽腫では 全例が治療後 1 5 5 月で死亡もしくは再発育, 再手術の 転帰をとっていた。一方, 他の神経膠腫 2 例( 陽子線と ${ }^{60} \mathrm{Co} \gamma$ 線併用治療で総線量 $86 \mathrm{~Gy}$ と $114.6 \mathrm{~Gy}$ ) は放射線治 療後 7〜9力月経ているが, Karnofsky值で70を示し, CT 上再発育徵候はみられていない(Fig. 3A〜D)。このうち 1 例に拈いて放射線治療後 5 力月目に軽度片麻㾇の出現が みられ，腫瘍再発育が疑われたが，CT 所見では増強域の 増大や周囲圧迫偏位所見もなく, 脳血管撮影にて照射部位 に一致して病巣主幹動脈の著しい狭窄が認められた(Fig. $3 \mathrm{E})$. この症例は glycerol $(1,000 \mathrm{~m} l /$ day $) の 1$ 週間静脈内 投与で片麻㾝の著明な改善が得られた。再発悪性铕膜腫の 
症例は矢状静脈洞に浸潤している残存腫湯部に陽子線治療 が行われた（総線量 $72.5 \mathrm{~Gy}$ )が. 治療後 7 力月目の追跡 CT では増強域を示していた残存部腫瘍は消失していた。 傍鞍部髄膜腫の症例(陽子線と ${ }^{60} \mathrm{Co} \gamma$ 線併用治療で総線量 $81.8 \mathrm{~Gy})$ においては内頸動脈に照射が及ばない治療法とし て行われたが, 治療後 6 カ月目の追跡 CT では腫瘍体積は
縮小を示し, 臨床的にも治療前にみられていた第而脳神経 圧迫症状が改善してきている.

陽子線治療による副作用は, 陽子線照射に基づく急性期 の脳浮腫, 脳圧え進症状は発現しなかったが, 総治療線量 $50 \mathrm{~Gy}$ 以上の 9 例全例において, $50 \mathrm{~Gy}$ を越す頃から照射 部の皮庸の発赤, 水疮形成, 糜爛などの放射線皮膚炎や食
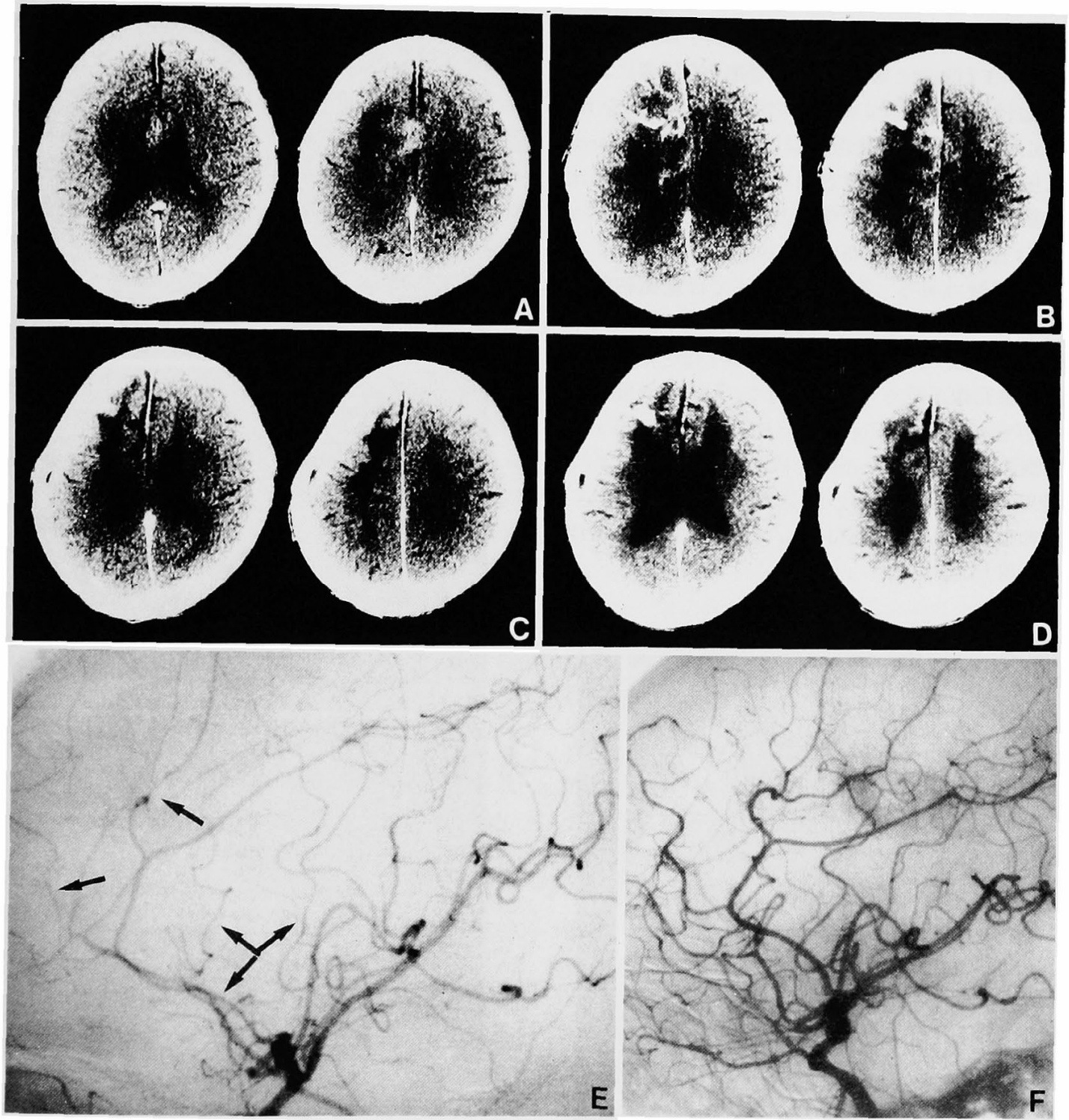

Fig. 3 Case 1, astrocytoma, grade II. A: Scan, taken before surgery, delineating a hypodense area with inhomogeneous contrast uptake in the left frontal region. B: Scan, taken after surgery, showing the partially enhanced residual tumor. A Teflon mesh which was embedded in the cavity after removal of the tumor in order to decide the range of the proton beam is shown as a high-dense line. C: Scan, taken after irradiation of $86 \mathrm{Grey}(\mathrm{Gy})$ [ ${ }^{60}$ cobalt (Co) $30.5 \mathrm{~Gy}$; proton $55.5 \mathrm{~Gy}$ ], showing the tumor decreased in size. D: Scan, taken 7 months after radiotherapy, showing the markedly decreased size. The Teflon mesh is observed as a high-dense nodule. E, F: Left carotid angiograms demonstrating narrow branches (arrows) of the anterior and middle cerebral arteries in the irradiated field 5 months after radiotherapy (E), in comparison with the same branches before surgery (F). 
欲減退，易疲労感が出現した。食欲減退，易疲労感は 1 週 間位で軽快したが，放射線皮膚炎は治療後も長期間にわた ってみられた. また, 抗痤攣剂常用量服用中にもかかわら ず，9例中 6 例，67\%に痤攀発作を認めた.

\section{$\mathrm{V}$ 組織学的検索}

当大学で再手術を行った多型性神経膠芽腫 2 例 ( 1 例は 陽子線治療中止例， 1 例は陽子線と ${ }^{60} \mathrm{Co} \gamma$ 線併用治療例） の組織学的検索を再手術直前の CT および陽子線線量分布 との関係において行った。すすおち，増強 CT 画像におい て増強部中心付近を tumoral area, 増強域の遠位部を remote tumoral area，その周辺低吸収域を peritumoral area として採取した標本の組織所見と照射された線量との対比 において検討した. Fig. 4 の症例は ${ }^{60} \mathrm{Co} \gamma$ 線 $30.2 \mathrm{~Gy}$,つ いで陽子線 $54 \mathrm{~Gy}$, 病巣総線量 $84.2 \mathrm{~Gy}$ を照射された 1 力 月後の再発育症例である。 Tumoral area では腫瘍細胞の 核融解, 核濃縮, 胞体の膨化, 無構造均質化した壊死組 織，血管壁硝子様化，コラーゲン線維の増生などから成る いわゆる凝固壊死像が認められる一方で, viable な腫瘍細 胞もかなり存在していた(Fig. 5A). Remote tumoral area では腫瘍細胞の密度が高く, 細胞の核や胞体に変化はみら れず，血管壁の変化にも乏しい所見であった(Fig. 5B). さらに, その外側の peritumoral area では細胞間隙の著明

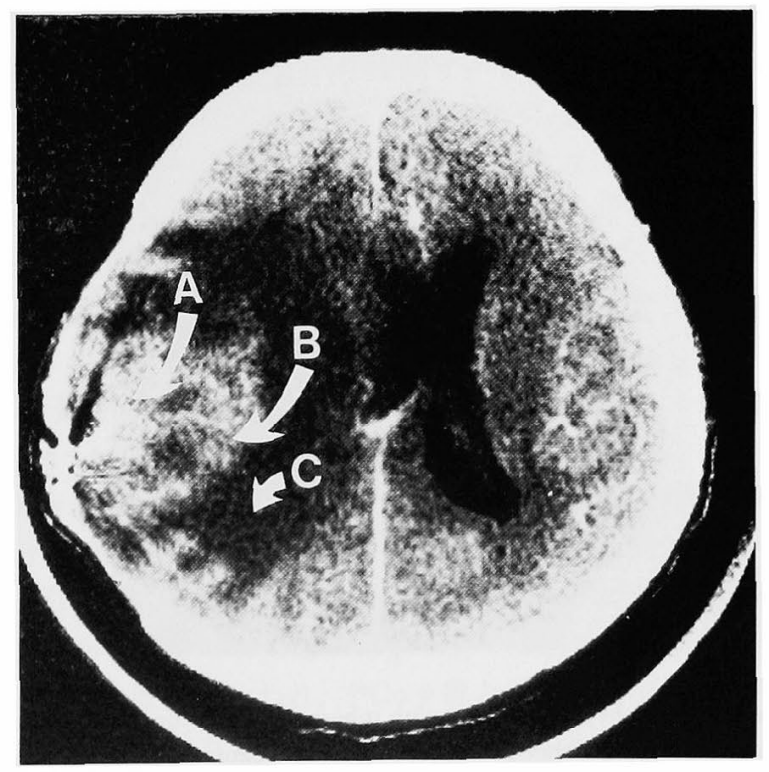

Fig. 4 Enhanced CT scan in Case 4, glioblastoma multiforme, taken 1 month after radiotherapy of $84.2 \mathrm{~Gy}\left({ }^{60} \mathrm{Co} 30.2\right.$ $\mathrm{Gy}$; proton $54.0 \mathrm{~Gy}$ ). Letters from A to $\mathrm{C}$ correspond to the $\mathrm{A}-\mathrm{C}$ in Fig. 5.
な疎性化, 肥大した astrocyte を認める浮腫組織の所見で, 構成細胞や血管壁にも著変は認められなかった(Fig. 5C).

\section{VI 考察}

1946年, Wilson ${ }^{21)}$ によって陽子線は多くの物理学的特性 を持ち、それを利用して腫瘳の治療に応用できると報告さ

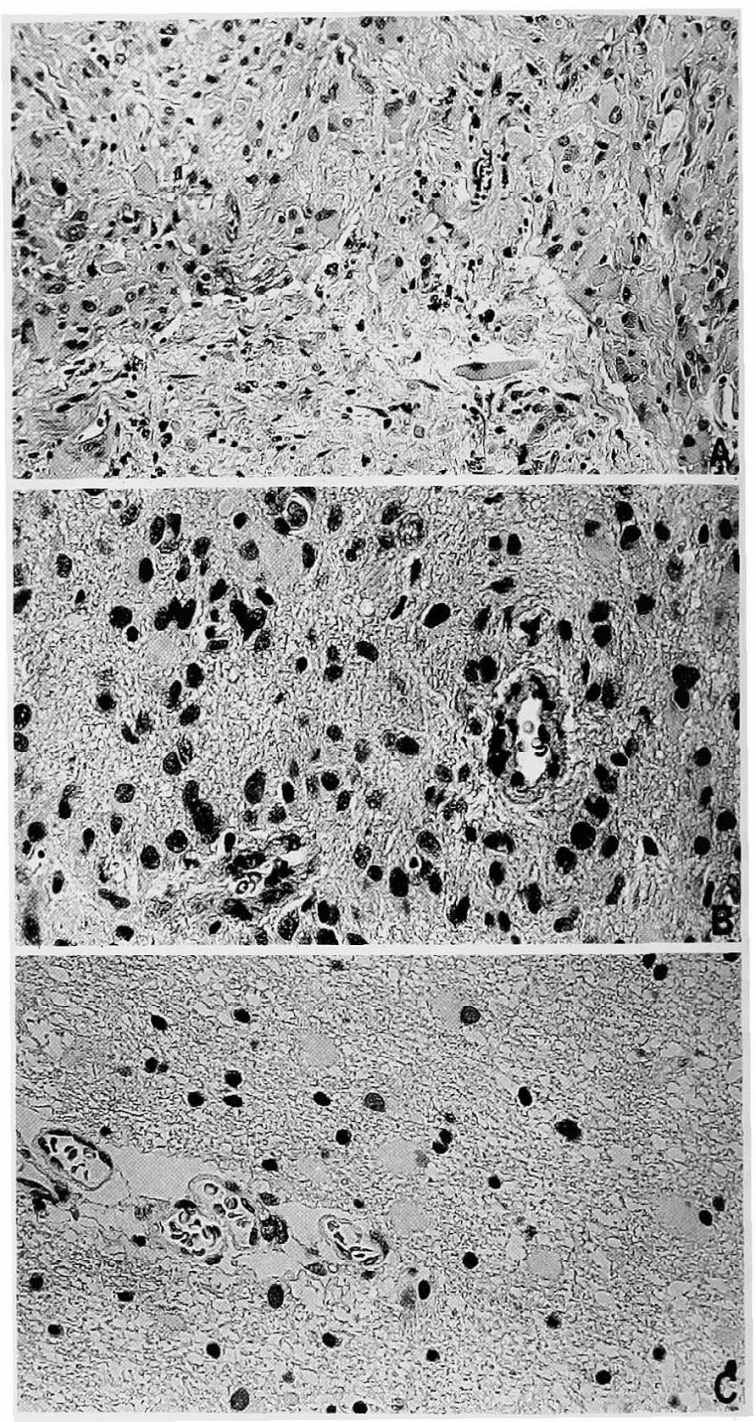

Fig. 5 Photomicrographs of the irradiated tissues removed by surgery after irradiation of $84.2 \mathrm{~Gy}$ in Case 4 . A: Coagulation necrosis and viable tumor cells from the central zone of the enhanced area on CT. Hematoxylin $\operatorname{eosin}(\mathrm{HE})$ stain, $\times 200$. B: Viable tumor cells and no thickening of the vessel wall from the border zone of the enhanced area on CT. HE stain, $\times 400$. C: Edematous brain tissue and no thickening of the vessel wall in the peritumoral area on CT. HE stain, $\times 400$. 
れた. 当初陽子線治療が期待されたもっとも大きな要素 は，X線や ${ }^{60} \mathrm{Co} \gamma$ 線と比較した場合，それらよりも高い 生物学的効果(RBE) を持つことや酸素堌強効果( oxygen enhancement ratio; 以下 OER)を無視できること，そして 飛程の最後で一挙にエネルギーを放出する効果(Bragg peak）を持っことであった．しかしながら Archambeau $ら^{3)}$ P Robertson ら ${ }^{15)}$ の報告により，RBEは0.98〜1.3, OERは2.5と X 線や ${ }^{60} \mathrm{Co} \gamma$ 線と比べてほとんど変りがな く，陽子線は RBEや OER の点では効果に期待が持てな いことが判った。したがって陽子線治療の最大の利点は, Bragg peakに表現される効率の良い線量分布や照射野の sharpnessにほかならない,1,17)。このことは脳組織にたと えれば，正常組織を傷害することなしに病巣部のみに集中 して多量の線量を照射できることを意味しており，脳腫瘍 治潦に適切と考えられる．中枢神経系組織においても陽子 線の sharpness は Andersson ら”によって実験的に確認さ れ，中枢神経系への臨床応用に手掛りを与えている.

神経膠腫に対する陽子線治療は，すでに Graffman ら $5^{6)}$ ， Munzenrider ら"11)よって報告されている. Graffman ら は $185 \mathrm{MeV}$ の陽子線を用い，7例の悪性神経膠腫の術後 に陽子線単独で総線量 $50 \sim 52 \mathrm{~Gy}$ を 4 週間に 9 11回の分 割で照射する治療法を行ったが，7例すべてが術後最短 10 カ月, 最長50カ月で死亡したと報告している，彼らの剖椮 所見では，陽子線照射による腫瘍組織の壊死像は認めてい るものの viable な腫場細胞も出現していたと報告されて いる，我々の組織所見も Graffman 5 $5^{6}$ の所見と同様であ ったが，彼らよりも多量の病巣総線量であるにもかかわら ず類似した所見を呈していたこと，さらにその上腫痬周辺 部は他の正常組織部よりも放射線傷害を受けやすいと言わ れている4,16)にもかかわらず，我々の所見では周辺低吸収 域部を含め，睡瘍中心部において放射線効果を示唆する所 見にそしかったことは注目すべきである。これらのこと は, (1)膠芽腫に対する抗腫煌効果線量は $84.2 \mathrm{~Gy}$ 以上が必 要である，(2)腫瘍組織が放射線になんらかの抵抗性を持っ ていた，(3)本治療法における陽子線線量分布に問題があ る，(4)病巣部の形状が複雑かつ不均質楧造のために不均等 補正の誤差 ${ }^{18)}$ が大きすぎたなどの問題を示唆しており，今 後さらに検討すべき課題と思われた.

脳腫場への陽子線治療の早期の副作用としては, 全例に 程度の差はあれ，照射入口部に放射線皮膚炎がみられたこ と，および67\%の症例に痙卛発作が出現したことである.

Munzenrider ら ${ }^{11}$ は $160 \mathrm{MeV}$ の陽子線で脳腫瘍に対して 50〜52 Gy の照射を行った症例に放射線皮膚炎がみられた と報告している，効率の良い線量分布を持っている陽子線 ではあるが, 残存部腫瘍量が多い場合には, 病巣すべてを
照射するためにおのおの飛程の異なる単一陽子線(おのお のの Bragg peak 幅は非常に狭い)を照射し，全体を加算す ることによって Bragg peak 幅を挔大するので，結果とし て基底線量も增大寸る，その場合，残存部腫湟が脳表から 存在しているような症例では照射入口部にも增大した基底 線量分が照射されてしまい，これが放射線皮膚炎を引き起 こすものと考えられた，したがってこの問題は，一つには 照射入口部を 2 ないし 3 門にすることにより改善されると 思われる，一方，痙戀発作が多発する原因としては，短期 間のうちに広範囲に多量の線量が照射されたことや線量分 布に問題があって正常組織にも照射されたことなどが考え られた．線量分布に起因すると思われるこれら副作用に関 $し て$ Nielsen $ら^{12,13}$ は, 組織学的に照射線量との関係から (1) $160 \mathrm{MeV}$ の陽子線治療後 $3 \sim 5$ 力月目に約 $20 \mathrm{~Gy}$ の陽 子線線束上の正常神経組織に壊死をきたし，これはX線 とほぼ同じ10)であること沼，(2)下垂体切除の目的で選択的 に下垂体に 100〜180 Gy の陽子線治療後 3 力月～4 年目に 側頭葉内側部に radionecrosisの所見がみられ，その部は 35〜50 Gy 照射されていたこと胡を報告している. 固型腫 瘍に対する放射線効果線量は照射時の腫場の大きさや分割 回数によって变ってくる201ので, 抗腫瘍効果のために線量 を多くしたい場合には，陽子線のような効率の良い線量分 布を持つ放射線が期待される. しかし，今回の副作用の出 現やNielsen らの報告 ${ }^{22,131}$ は, 陽子線に注線量分布や照射 法の点でまだ改善すべき問題があることを示唆している.

陽子線治療の脳外科領域への応用は, 陽子線の物理学的 性質である Bragg peakにより非常に魅力的である。しか しながら神経膠腫, 膠芽腫への臨床応用は, preliminary report ${ }^{6,11)}$ ではあるが長期生存例の報告はない，この原因 は脳腫淔治療への陽子線の至適条件が未解明であることに もよっている.こうした観点から, 我々の10例の臨床経験 から得た陽子線治療法の脳腫瘍応用に関する問題点として は，(1)陽子線の腫場内における至適線量分布の確立，(2)抗 腫瘍効果のための至適線量配分の確立, (3) 2 あるいは 3 門 照射などの照射法の改善や他の放射線治療との併用におけ る至適条件の確立, (4)放射線との相互作用の期待される薬 剂併用の検討などが考えられた．今後これらの問題点を検 討, 改善していけば，陽子線も有力な脳腫瘍治療法の一つ となるに違いない。

\section{VII 結 語}

1. 術後脳腫瘍 10 例( 神経膠腫 3 例，多型性神経膠芽腫 5 例, 蹃膜腫 2 例)に対して $250 \mathrm{MeV}$ の陽子線による単独 治療あるいは ${ }^{60} \mathrm{Co} \gamma$ 線との併用治療を行い，組織学的に 本治療法に関する検討を行った。 
2. 陽子線治療後の早期の副作用としては, 治療を終了 しえた 9 例全例に照射入口部の放射線皮膚炎がみられ，ま たうち 6 例 $(67 \%)$ に痙摮発作がみられた。

3. 本治療法は神経膠腫，随膜腫例には効果が期待され たが，多型性神経膠芽腫例には効果不良で，いくつかの改 善点が检討された。

4. 今後脳腫瘍に対して陽子線治療を応用するに当り， 改善もしくは確立すべき方法が検討された。

終りに，本研究の一部は昭和59年度文部省科学研究費がん特 （2）No. 59015020の援助によるものであり，ここに謝意を表しま 寸.

本論文の要旨は，第22回日本癌治療学会総会(1984年9月，東 京において発表した。

\section{文献}

1) Andersson B, Larsson B, Leksell L, Mair W, Rexed B, Sourander P: Effect of local irradiation of the central nervous system with high energy protons, in Haley TJ, Snider RS (eds): Response of the Nervous System to Ionizing Radiation. New York, Academic, 1962, pp 345-358

2）安藤興一,小池幸子，河内清光，平岡 武，大原 弘，横 田昌彦, 稲田哲雄, 広川裕, 佐藤真一郎, 江口清美, 浦野 宗保：治㙩用陽子線の細胞致死効果，日医放線会誌 45：531535,1985

3) Archambeau JO, Bennett GW, Levine GS, Cowen R, Akanuma A: Proton radiation therapy. Radiology 110: 445-457, 1974

4) Burger P, Mahaley MS, Dudka L, Vogel FS: The morphologic effects of radiation administered therapeutically for intracranial gliomas. A postmortem study of 25 cases. Cancer 44: 1256-1272, 1979

5) Elkind MM, Sutton $H$ : Radiation response of mammalian cells grown in culture. I. Repair of $x$-ray damage in surviving Chinese hamster cells. Radiat Res 13: 556-593, 1960

6) Graffman S, Haymaker W, Hugosson R, Jung B: High-energy protons in the postoperative treatment of malignant glioma. Acta Radiol [Ther] (Stockh) 14: 443-461, 1975

7）稲田哲雄, 早川吉則, 丸橋 晃, 大原 絜, 北川俊夫, 秋 貞雅祥，河内清光，金井達明：高エネルギ一垂直陽子線治療 装置. 日医放線会誌 $44: 844-853,1983$

8）稲田雄, 早川吉則, 大原 潔, 丸橋 晃, 平松慶博, 秋
貞雅祥：高エネルギー陽子線治療計画法に関する研究，日医 故線会誌 43: 781-793, 1982

9) Larsson B: Pre-therapeutic physical experiments with high energy protons. Br J Radiol 34: 143-151, 1961

10) Lindgren $M$ : On tolerance of brain tissue and sensitivity of brain tumors to irradiation. Acta Radiol [Suppl] (Stockh) 170:173,1958

11) Munzenrider JE, Shipley WU, Verhey LJ: Future prospects of radiation therapy with protons. Semin Oncol 8: 110-124, 1981

12) Nielsen SL, Kjellberg RN, Asbury AK, Koehler AM: Neuropathologic effects of proton-beam irradiation in man. I. Dose-response relationships after treatment of intracranial neoplasms. Acta Neuropath (Berlin) 20: 348-356, 1972

13) Nielsen SL, Kjellberg RN, Asbury AK, Koehler AM: Neuropathologic effects of proton-beam irradiation in man. II. Evaluation after pituitary irradiation. Acta Neuropath (Berlin) 21 $76-82,1972$

14) Puck TT, Markus PI: Action of $x$-rays on mammalian cells. $J$ Exp Med 103: 653-666, 1956

15) Robertson JB, Williams JR, Schmidt RA, Little JB, Flynn DF, Suit HD: Radiobiological studies of a high-energy modulated proton beam utilizing cultured mammalian cells. Cancer 35: 16641677,1975

16) Schiffer D, Giordana MT, Soffietti R, Tarenzi L, Milani R, Vasario E, Paeletti P: Radio- and chemotherapy of malignant gliomas. Pathological changes in the normal nervous tissue. Acta Neurochir (Wien) 58: 37-58, 1981

17) Stenson S: Effects of high-energy protons on healthy organs and malignant tumours. Acta Universitatis Upsaliensis 73: 1-21, 1969

18) Suit HD, Goiten M, Tepper J: Clinical experience and expectations with protons and heavy ions. Int $J$ Radiat Oncol Biol Phys 3 : 115-125, 1977

19) Suit HD, Goiten M, Tepper J, Koehler AM, Schmidt RA, Schneider R: Exploratory study of proton radiation therapy using large field techniques and fractionated dose schedules. Cancer 35: 1646-1657, 1975

20) Suit $H D$, Wette R: Radiation dose fractionation and tumor control probability. Radiat Res 29: 267-281, 1966

21) Wilson RR: Radiological use of fast protons. Radiology 47: 487491,1946

〔別刷請求先：干305 茨城県新治郡桜村天久保3-1-1, 筑波大学 臨床医学系脳神経外科, 吉井与志颜] 